\title{
Modifikasi Rumah Kolonial untuk Usaha Mandiri di Semarang
}

\author{
(Modification of Colonial House for Independent Businesses in Semarang) \\ Antonius Ardiyanto, Rudyanto Susilo, Valentinus Suroto dan Hudi Prawoto \\ Fakultas Arsitektur dan Desain Universitas Katolik Soegijapranata \\ JI. Pawiyatan Luhur IV, Semarang \\ ardi_diet@yahoo.com
}

\begin{abstract}
Semarang city there are many residential buildings built in the colonial period. Colonial dwelling house is spread in various areas of Semarang city, such as in the residential area of Candi in the upper city. This area in the colonial period is an elite residential area with a fairly large building area of about $1000 \mathrm{~m} 2$ which is planned as a water absorption area for water reserves in the lower cities. Some colonial residential buildings today have been converted to function as a place of business such as café or restaurant. The transfer function of the residential building into a place of business is done by modifying the existing space adjusted for the space character for the type of business. The purpose of this study is to know how the modification of the colonial house, especially in the spatial in maximizing space as a place of independent business. The research was conducted by descriptive method, with the sample taken by purposive. The results showed that the modification of the colonial house to independent business is manifested in the change of function of the living room into a space of business which is adapted to the specificity of its business activity. In addition, the addition and alteration of building materials is used to emphasize the main functions of the business. While in general plan of building of main house stay tends not change.
\end{abstract}

Keywords : colonial house, modification, independent bussiness

\begin{abstract}
ABSTRAK
Kota Semarang terdapat banyak bangunan rumah tinggal yang dibangun pada masa kolonial. Rumah tinggal kolonial tersebut tersebar diberbagai wilayah kota Semarang, diantaranya di kawasan permukiman Candi di kota atas. Kawasan ini pada masa kolonial merupakan kawasan permukiman elit dengan lahan bangunan yang cukup luas sekitar $1000 \mathrm{~m} 2$ yang direncanakan sebagai daerah peresapan air untuk cadangan air di kota bawah. Beberapa bangunan rumah tinggal kolonial saat ini telah dialih fungsikan sebagai tempat usaha seperti café atau restoran. Alih fungsi bangunan rumah tinggal menjadi tempat usaha dilakukan dengan memodifikasi ruang yang ada disesuaikan untuk karakter ruang untuk jenis usahanya.

Tujuan dari studi ini adalah mengetahui bagaimana bentuk modifikasi rumah kolonial khususnya dalam tata ruang dalalamnya dalam memaksimalkan ruang sebagai tempat usaha mandiri. Penelitian dilakukan dengan metoda deskriptif, dengan sampel diambil secara purposive. Hasil penelitian menunjukan bahwa modifikasi rumah kolonial untuk usaha mandiri diwujudkan dalam perubahan fungsi ruang - ruang tempat tinggal menjadi ruang tempat usaha yang disesuaikan dengan kekhususan kegitan usahanya. Selain itu, penambahan dan perubahan material bangunan digunakan untuk memberi penekanan pada fungsi utama pada kegiatan usaha tersebut. Sedangkan secara umum denah bangunan rumah tinggal utama cenderung tidak berubah.
\end{abstract}

Kata Kunci : Kolonial, Usaha, Modifikasi 


\section{PENDAHULUAN}

Modifikasi fungsi bangunan atau adaptive reuse, yang memiliki relevansi yang lebih besar terhadap masalah masalah kota saat ini kota, dan merupakan perhatian utama dari siapa pun mempertimbangkan nasib bangunan tertentu. Untuk menyelidiki isu - isu yang berkaitan dengan penggunaan baru yang cenderung fungsional dan secara finansial layak untuk bangunan yang ada, yang diperlukan penelitian untuk menjelajahi kompleksitas praktek yang ada dalam adaptasi tersebut. Untuk melakukan ini itu diperlukan untuk mengidentifikasi dan mengkategorikan semua pemain utama yang terlibat dalam membuat keputusan dan melaksanakan proyek perbaikan adaptif pada saat ini, dari keuangan pengguna. (Ardiyanto, 2010)

Tetapi di lain pihak (dalam sudut pandang masyarakat), sistem ini tidak banyak melibatkan partisipasi dari masyarakat, sehingga menciptakan gap (jarak) antara warisan budaya dan masyarakatnya. Oleh karena itu, saat ini perlu dibuat suatu pendekatan baru dengan menggabungkan dua pendekatan tersebut dan memberikan ruang yang luas bagi partisipasi masyarakat dalam pelestarian bangunan cagar budaya. (Yulita, 2011)

Rumah dengan segala perwujudan bentuk, fungsi dan maknanya senantiasa diatur, diarahkan dan ditanggapi atau diperlakukan oleh penghuni menurut kebudayaan yang mempengaruhi masyarakat setempat. (Sukawi, 2009)

tinggal terjadi terutama adanya perkembangan kebutuhan dan fungsi pada rumah tinggal. Penelitian Aryani, Wahyuningsih dan Mulyadi, 2016, tentang transformasi rumah inti Perumnas menunjukkan bahwa terjadi kecenderungan penguhuni rumah untuk memodifikasi rumahnya dengan penambahan ruang. Penambahan ruang tidur merupakan kasus yang paling banyak terjadi. hal terserbut dikarenakan ketidaksesuaian jumah anggota keluarga dengan fasilitas yang ditawarkan. Hal yang sama kemungkinan menjadi dasar kenambahan kamar mandi.

Lestari, Khaliesh, Zain dan Sari, 2017, meneliti tentang modifikasi yang dilakukan penghuni rumah pada rusunawa di Pontianak. Hasil penelitian menunjukkan bahwa Jumlah ruang yang tersediadan keterbatasan luasan memunculkan usaha penghuni untuk melakukan penyesuaian dalam memanfaatkan ruang sesuai dengan kebutuhannya. Modifikasi ruang terjadi pada selasar dan balkon.

Rumah kolonial sebagai warisan budaya yang telah berfungsi melewati rentang jaman, perlu perlakuan khusus ketika akan digunakan dengan fungsi baru. Memodifikasi rumah kolonial sekaligus memanfaatkannya untuk kegiatan usaha dan melestarikannya merupakan suatu usaha dengan kesadaran penghargaan terhadap arsitektur rumah tinggal kolonial yang khas yaitu arsitektur Indis.

Masyarakat masa kini secara umum masih menyukai arsitektur masa lalu, dan ingin bernostalgia untuk mengalami ruang masa lalu. Menurut Carolina, ---, peminat terhadap ruang nostalgia mulai dari wisatawan mancanegara, wisatawan lokal, budayawan, arsitek yang menyukai keindahan bangunan kolonial, kolektor, pebisnis, mahasiswa dan masyarakat luas. Keseluruhan pihak tersebut memiliki latar belakang dan maksud yang berbeda-beda pada restoran kolonial. Modifikasi rumah tinggal kolonial untuk usaha restoran memberikan ruang untuk apresiasi masyarakat pada arsitektur kolonial. Bangunan rumah kolonial yang telah menjadi bangunan cagar budaya di Semarang yang telah dimodifikasi dan dimanfaatkan untuk kegiatan usaha perlu diteliti keberadaanya.

\section{METODE PENELITIAN}

Metode pengumpulan data dilakukan dengan cara studi dokumentasi bangunan kolonial yang dilestarikan dengan pengukuran bangunan, data tata ruang bangunan dan perubahannya dan wawancara. Studi dokumentasi ditujukan untuk mendapatkan gambaran tentang bentuk bangunan kolonial dilihat dari aspek 
struktur, tata ruang maupun nilai arsitektur dari bangunan tersebut.

Metode wawancara akan dilakukan dalam bentuk komunikasi antara peneliti dengan sejumlah pemilik bangunan dan responden.

$\begin{array}{lr}\text { Pengumpulan data dilakukan } \\ \text { melalui observasi langsung pada } \\ \text { bangunan yang menjadi kasus penelitian. } \\ \text { Sampel penelitian } & \text { ditentukan } \\ \text { menggunakan purposiverrampling }\end{array}$ (Creswell, 2009), yaitu pengambilan sampel yang dilakukan secara sengaja dengan tujuan tertentu dalam rangka penggalian informasi berkenaan dengan pendekatan pelestarian bangunan kolonial oleh masyarakat secara mandiri di Semarang.

\section{Modifikasi Rumah Kolonial Untuk Usaha Mandiri di Semarang}

Dalam penelitian ini diambil dua kasus bangunan kolonial yang dimodifikasi untuk usaha mandiri yaitu Goodfellas Resto dan Jonas Photo yang berada di Kawasan Candi Semarang.

Status kepemilikan lahan dan bangunan Goodfellas Resto dan Jonas Foto adalah sewa pada pemilik bangunan rumah tinggal kolonial.

Modifikasi rumah kolonial yang dijadikan usaha mandiri ini, khususnya Goodfellas Resto dan Jonas Photo samasama menyewa rumah kolonial tersebut dilakukan dengan tidak mengubah arsitektur bangunannya. Perubahan sedikit terjadi pada interiornya untuk menyesuaikan jenis usaha yang dilakukan dengan mengutamakan pelestarian bentuk interiornya dengan menjaga orisinalitannya.

Tabel 1. Status Kepemilikan Lahan dan Bangunan Goodfellas Resto dan Jonas Photo (Sumber : Analisis Pribadi,2017

\begin{tabular}{cccc}
\hline Nama Bangunan & $\begin{array}{c}\text { Alih } \\
\text { Fungsi } \\
\text { Bangu } \\
\text { nan }\end{array}$ & $\begin{array}{c}\text { Status } \\
\text { Kepemili } \\
\text { kan } \\
\text { (Awal) }\end{array}$ & $\begin{array}{c}\text { Status } \\
\text { Kepemil } \\
\text { ikan } \\
\text { (Akhir) }\end{array}$ \\
\hline
\end{tabular}

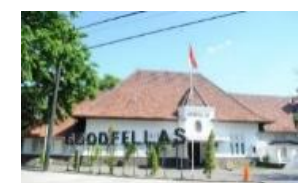

Goodfellas Resto

\section{Rumah \\ Tinggal}

Restora

Pemilik Kel. Liem

Sewa
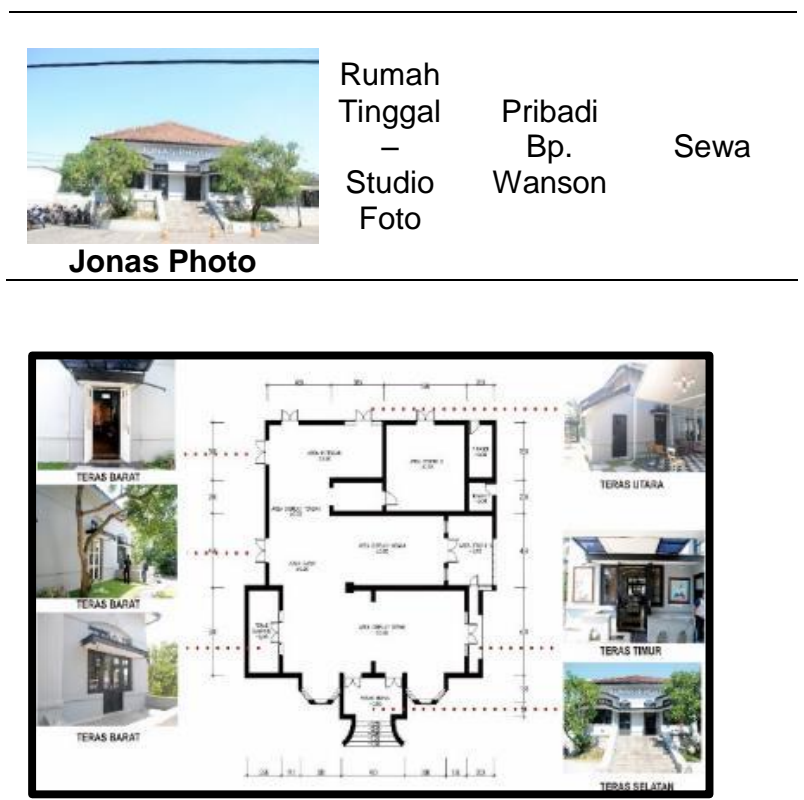

Gambar 1: Denah dan Foto Suasana LuarJonas Photo

(Sumber : Dokumen Survey,2017)

Untuk Modifikasi rumah tinggal yang terjadi pada bangunan Jonas Photo ini hanyalah pada fungsi ruang dan pada penambahan box studio yang berada di belakang bangunan ruan display Jonas Photo. Penambahan ini terjadi pada lahan rumah kolonial yang sangat besar ini, sehingga disebelah studio foto dibangunlah restaurant bernama Giggle Box.

Untuk fasad luar / tampak eksterior pada rumah kolonial ini tidak ada perubahan, justru dipertahankan. Karena pada hakikatnya masyarakat yang berkunjung tidak hanya tertarik pada studio foto yang ada di jonas, justru mereka tertarik pada fasad rumah kolonial yang unik ini. 


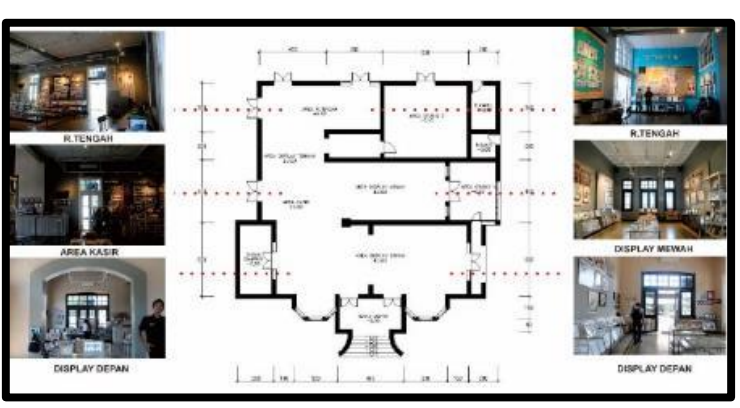

Gambar 2: Denah dan Foto Suasana Ruang Jonas Photo

(Sumber: Dokumen Survey, 2017)

Interior rumah kolonial yang didominasi beralih fungsi menjadi ruang display foto, masih menggunakan material original untuk menjaga ke-aslian bangunan. Untuk perawatan bangunan, pengelola Jonas Photo kesusahan dalam mencari ubin lantai yang sama dengan motif asli. Pengelola hanya memberikan perawatan berupa menambah semen, apabila terjadi kerusakan pada lantai tersebut.

Begitu juga pada atap bangunan, material sama sekali tidak diubah oleh pengelola, pada saat terjadi kebocoran pengelola berusaha menjaga keoriginalan dengan cara mengambil genteng yang paling bawah di tempelkan pada bagian genteng yang rusak. Bahkan tembok jonas photo yang diketahui sangat rapuh, pengelola tidak berusaha untuk membokar dan memodifikasinya.

\section{Modifkasi Alih Fungsi Ruang}

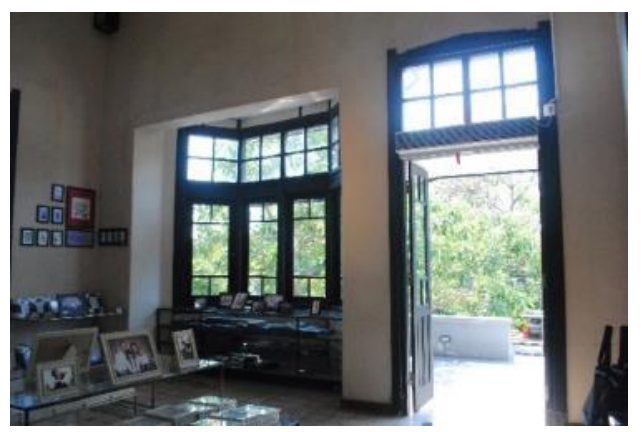

Gambar 3: Suasana Ruang Tamu yang berubah menjadi Ruang Display di Jonas Photo
(Sumber: Dokumen Survey, 2017)

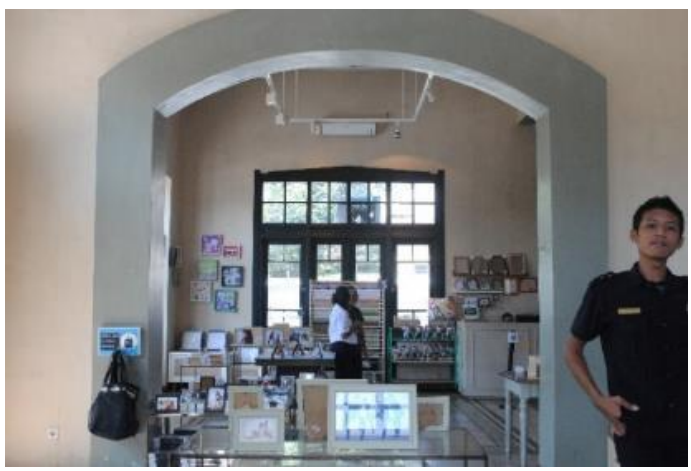

Gambar 4: Ssuasana Ruang Tamu yang berubah menjadi Ruang Display di Jonas Photo (Sumber: Dokumen Survey, 2017)

Terakhir ini, Jonas Photo merupakan Rumah Tinggal milik Bapak Wanson. Sebelum dijadikan ruang display untuk foto, ruang tersebut difungsikan sebagai ruang tamu. Pada saat ini modifikasi hanya terjadi pada alih fungsi ruang saja. Untuk materialnya pengelola Jonas Photo tidak merubah dari keaslian, tetapi justru merawarnya. Contoh seperti keaslian lantai berikut ini.

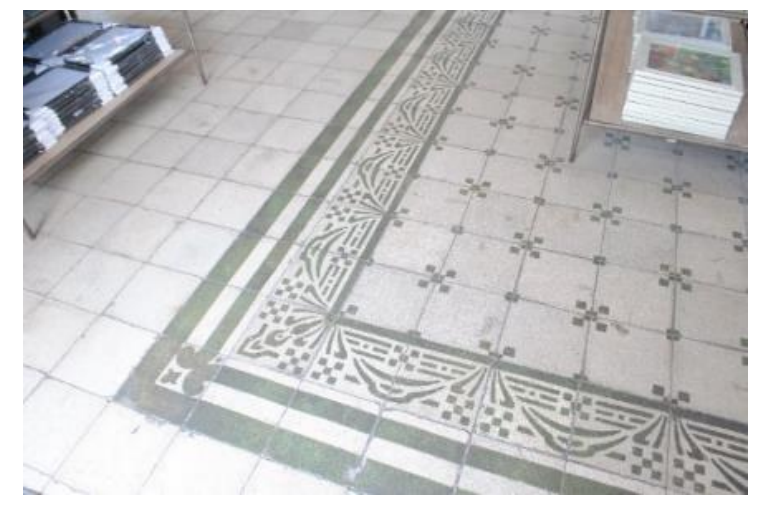

Gambar 4 : Keaslian Lantai yang masih dijaga oleh Pengelola Jonas Photo (Sumber: Dokumen Survey,2017)

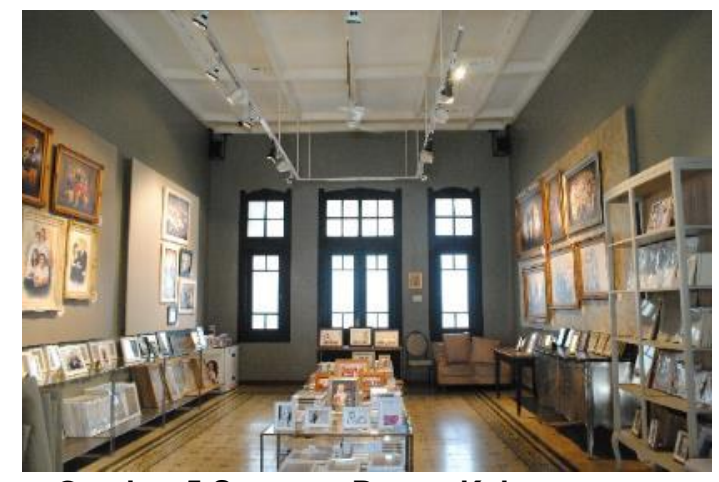

Gambar 5 Suasana Ruang Keluarga yang berubah menjadi Ruang Display dan Ruang Studio Foto di Jonas Photo

Tesa Arsitektur Volume 15| Nomor 2 | 2017 
(Sumber: Dokumen Survey,2017)

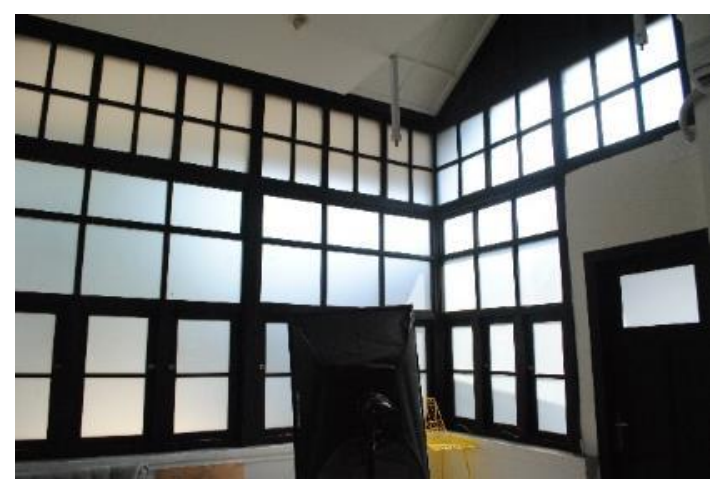

Gambar 6: Suasana Ruang Keluarga yang berubah menjadi Ruang Display dan Ruang Studio Foto di Jonas Photo

(Sumber: Dokumen Survey,2017)

\section{Goodfellas}

Pada tahun 1922 Goodfellas merupakan Rumah Tinggal Thio Thiam Tjong (18961969). Hingga pada tahun 1955 dijual kepada keluarga Liem, dengan sedikit perubahan-perubahan yang terjadi. Hingga pada akhirnya, rumah kolonial ini pada tahun 2014 berubah alih fungsi menjadi Restaurant Goodfellas.
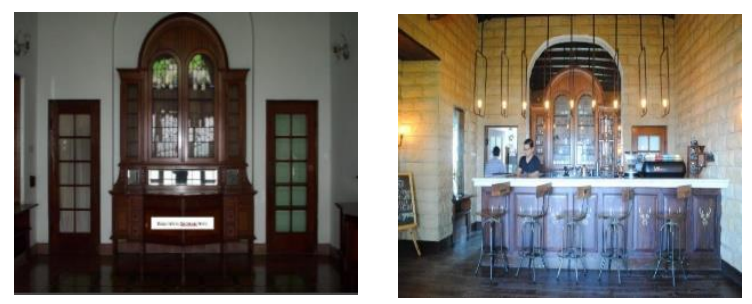

Gambar 7: Suasana Ruang Makan yang berubah menjadi Bar di Goodfellas (Sumber: Dokumen Survey, 2017)

Ruang Bar yang kini dapat dijumpai dalam Goodfellas, dahulunya berfungsi sebagai Ruang Makan pada Rumah Tinggal.
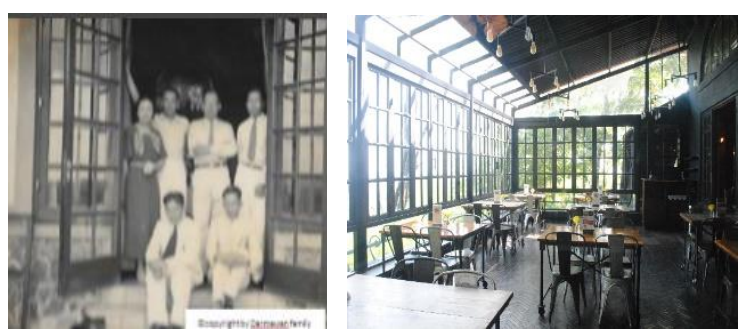

Gambar 8: Suasana Teras yang berubah menjadi Ruang Makan di Goodfellas

(Sumber: Darmawan, 2010, Dokumen Survey,2017)
Ruang Makan yang memiliki view sangat baik pada Goodfellas ini, dan sering sekali menjadi tempat favorit pengunjung untuk berfoto, dahulunya merupakan Teras pada Rumah Tinggal.

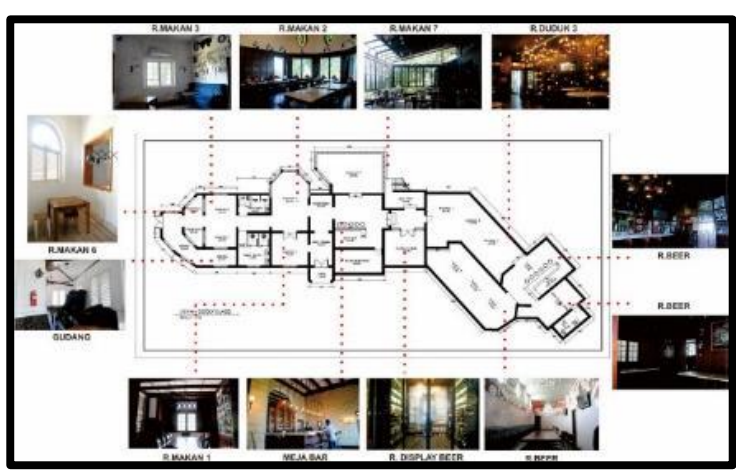

Gambar 9 : Denah dan Foto suasana ruang Goodfellas

(Sumber : Dokumen Survey,2017)

Modifikasi yang terjadi pada rumah kolonial yang menjadi Goodfellas Resto ini juga sama seperti Jonas Photo dominasi dengan perubahan alih fungsi ruang. Namun, pada Goodfellas Resto, modifikasi lebih terasa. Seperti ruang teras yang diubah menjadi ruang makan. Material lantai asli yang ditutup menjadi material kayu parquet untuk menambah konsep suasana pada interiornya.
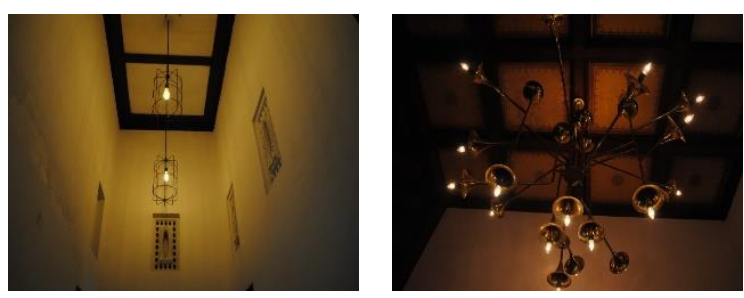

\section{Gambar 10 : Suasana Plafond Original Yang Di Tambah Hiasan Lampu}

(Sumber: Dokumen Survey,2017)

Plafond pada Goodfellas ini tidak megalami perubahan yang signifikan, namun modifikasi yang terjadi hanya pada penambahan lampu-lampu vintage yang menambah keindahan pencahayaan pada interiornya, sehingga menjadi daya tarik tersendiri bagi para pengunjung yang datang.

\section{Pemanfaatan Bangunan Kolonial untuk Usaha Mandiri}

\begin{tabular}{|c|c|c|}
\hline $\begin{array}{c}\text { Nama } \\
\text { Bangunan }\end{array}$ & $\begin{array}{c}\text { Kondisi Awal } \\
\text { (Asli) }\end{array}$ & $\begin{array}{c}\text { Kondisi } \\
\text { Sekarang }\end{array}$ \\
\hline
\end{tabular}

Tesa Arsitektur Volume 15| Nomor 2 | 2017 


\begin{tabular}{|c|c|c|}
\hline & & $\begin{array}{c}\text { (Pemanfaatan } \\
\text { Bangunan) }\end{array}$ \\
\hline $\begin{array}{l}\text { Goodfellas } \\
\text { Resto }\end{array}$ & $\begin{array}{l}\text { Dibangun } \\
\text { sesuai } \\
\text { dengan } \\
\text { material yang } \\
\text { di } \\
\text { rencanakan. } \\
\text { Seperti } \\
\text { material lantai } \\
\text { (papan } \\
\text { terasso), atap, } \\
\text { kusen, dll }\end{array}$ & $\begin{array}{l}\text { Perubahan } \\
\text { yang terjadi } \\
\text { pada alih } \\
\text { fungsi ruang, } \\
\text { material lantai } \\
\text { yang menjadi } \\
\text { papan } \\
\text { kayu/parket. }\end{array}$ \\
\hline $\begin{array}{l}\text { Jonas } \\
\text { Photo }\end{array}$ & $\begin{array}{l}\text { Hanya } \\
\text { terbangun } \\
\text { satu } \\
\text { bangunan inti } \\
\text { saja yaitu } \\
\text { rumah tinggal. } \\
\text { Bangunan } \\
\text { kolonial } \\
\text { dipertahankan } \\
\text { dalam bentuk } \\
\text { aslinya mulai } \\
\text { dari warna } \\
\text { dan material } \\
\text { kusen, lantai, } \\
\text { dan warna } \\
\text { yang ada di } \\
\text { dalam } \\
\text { bangunan. }\end{array}$ & $\begin{array}{l}\text { Saat berubah } \\
\text { alih fungsi } \\
\text { sebagai } \\
\text { tempat usaha, } \\
\text { penambahan } \\
\text { massa } \\
\text { bangunan } \\
\text { baru muncul } \\
\text { sesuai dengan } \\
\text { kebutuhan } \\
\text { penunjang } \\
\text { untuk } \\
\text { melengkapi } \\
\text { fasilitas dari } \\
\text { tempat usaha } \\
\text { tersebut. } \\
\text { Perubahan } \\
\text { yang terjadi } \\
\text { yaitu pada } \\
\text { fungsi ruang- } \\
\text { ruangnya } \\
\text { yang sekarang } \\
\text { di optimalkan } \\
\text { untuk display } \\
\text { foto. }\end{array}$ \\
\hline
\end{tabular}

Tabel 2: Pemanfaatan Bangunan Kolonial untuk Usaha Mandiri (Sumber : Analisis Pribadi,2017)

\section{PENUTUP}

\section{Kesimpulan}

Dari hasil pembahasan tentang modifikasi bangunan kolonial untuk usaha mandiri dapat disimpulkan bahwa:

1. Bangunan rumah tinggal kolonial untuk usaha dimodifikasi khususnya pada tata ruang dalamnya untuk kepentingan usaha.

2. Modifikasi tata ruang rumah kolonial untuk usaha cenderung mempertahankan dan melestarikan keaslian interior bangunannya.

3. Untuk restoran Goodfellas dan Jonas Photo ekterior bangunan sedikit modifikasi ruang khususnya ruang belakang untuk kepentingan usaha.
4. Interior bangunan pada restoran Goodfellas ada modifikasi pada lantai dan dinding, sedangkan pada Jonas Photo pada dinding sebagai area pajang foto dan frame hasil foto.

\section{DAFTAR PUSTAKA}

Ardiyanto, A, 2010."Strategi Konservasi Bangunan Bersejarah dengan Adaptive Reuse, Studi Kasus di Kota Semarang", Seminar Nasional Riset Arsitektur dan Perencanaan (Serap\#1), 16, Januari 2010, Pasca Sarjana Fakultas Teknik Universitas Gadjah Mada.

Aryani, Mona, S., Wahyuningsih, Siti, I.S., Mulyadi.2016."Evaluasi Rumah Inti Tumbuh Perumnas Berdasarkan Kecenderungan Transformasi Desain", Tesa Arsitektur volume 14 no 2 tahun 2016

Carolina, A., -----: "Nostalgia SpaceColonial Restourant Braga, Bandung", Jurnal Tingkat Sarjana Bidang Senirupa dan Desain.

Cresswell, J.W., 2009. Research Design; Qualitative, Quantitative and Mix Method Approach, Sage, Los Angeles

Darmawan, AMS. 2010, "Puri Gajah Mungkur", Seminar IAI, Gedung Lawang Sewu Semarang

Sukawi, 2009. "Pengaruh Arsitektur Indis Pada Rumah Kauman Semarang", Jurnal Tesa Arsitektur, Volume 7 Nomor 1 Juni 2009.

Sunarimahinsih, Y.T.,Dewi, T.N., Susanti, B.T.,2011."ModelPengelolaan

Bangunan Cagar Budaya Berbasis Partisipasi Masyarakat Sebagai Upaya Pelestarian Warisan Budaya", SeriKajianllmiah, Volume14,Nomor11,J anuari2011. 